\title{
The blind man of John 9 as a paradigmatic figure of the disciple in the Fourth Gospel
}

\author{
Author: \\ B. Vincent Muderhwa \\ Affiliation: \\ ${ }^{1}$ Department of New \\ Testament and Early Christian \\ Studies, University of South \\ Africa, South Africa \\ Note: \\ Dr Vincent Muderhwa was \\ a post-graduate student \\ of Prof. Dr Dirk G. van der \\ Merwe in the Department \\ of New Testament and Early \\ Christian Studies at the \\ University of South Africa, \\ South Africa. \\ Correspondence to: \\ Vincent Muderhwa \\ Email: \\ vincentmuder@yahoo.fr \\ Postal address: \\ Ulpgl-Goma, PO Box 468 \\ Gisenyi, Rwanda \\ Dates: \\ Received: 01 Dec. 2010 \\ Accepted: 14 Apr. 2011 \\ Published: 16 Mar. 2012 \\ How to cite this article: \\ Muderhwa, B.V., 2012, 'The \\ blind man of John 9 as a \\ paradigmatic figure of the \\ disciple in the Fourth Gospel', \\ HTS Teologiese Studies/HTS \\ Theological Studies 68(1), \\ Art. \#1008, 10 pages. http:// \\ dx.doi.org/10.4102/hts. \\ v68i1.1008
}

(C) 2012. The Authors.

Licensee: AOSIS

OpenJournals. This work

is licensed under the

Creative Commons

Attribution License.
This article seeks to compare Christian discipleship with Mosaic discipleship. The Pharisees, needing to survive, rejected the Christological revelation the Son of Man brought in order to make God known on earth. The study of discipleship in John 9 leads us to understand that 'discipleship in Moses' which seeks to please God by upholding the Law or Torah is no longer defensible. Discipleship in chapter 9 redefines the believer's covenant relationship with God and demonstrates how it takes place in the person of Jesus (the envoy motif) and in his work (functional Christology) in order that the disciple may follow him into the light. The portrayal of the blind man as a role model of the disciple implicitly explains how Christology played a major role in an environment of conflict and ideology and how it relates discipleship to the devotion of Jesus as the plenary manifestation of God.

\section{Introduction}

This article endeavours to understand how the healed blind man of John 9 came to be seen not only as the hero of John's narrative but also as a role model for disciples. To deal with the blind man as a model disciple, one must first begin by understanding how Johannine scholarship reads John 9. A useful second step is to comprehend the unusual expressions disciples of Moses' and which the Pharisees proudly apply to themselves in John 9.28-29. In doing so they establish that they do not consider themselves to be disciples of Jesus and they claim to know about God's way of revelation. They constructed an ideology around Moses and Jesus at the same time. The strong and audacious attitude of the healed blind man in John 9 vis-à-vis Jesus in this environment of intense conflict helps us to discover how the Fourth Evangelist came to conceive of him as a role model for disciples towards the end of the 1st century.

This inquiry takes as its point of departure how scholars read John 9 as a 'window' into the world of John with reference to the social and historical issues that lie behind the text. Then we will deal with the source and theological consistency of the expression 'disciples of Moses' before coming to the meaning and implications of being a disciple of Jesus in the light of John 9.

\section{The Johannine community and discipleship Brown, Martyn, Schnackenburg, Moody Smith and Köstenberger}

In order to understand how the blind man came to be viewed as a paradigmatic figure of the disciple as a consequence of the Johannine community's experience, it is best to begin with how scholars used John 9 as this allows us to reconstruct the circumstances that surrounded the authorship of this chapter and the nature of the social system within which the text originated. In this section, we will discuss how Brown, Martyn, Schnackenburg, Moody Smith and Köstenberger strive to deal with the issue of discipleship by referring to John 9.

Brown's (1978) penetrating reconstruction of the history of an independent Johannine community traces four stages, three of which are the following:

- At the first stage, before the writing of the Gospel, the Beloved Disciple, as an ex-disciple of John the Baptist in light of 1.35-41, and a follower of Jesus from the start of his ministry, was designated by a group of scholars as a leading figure of the Gospel, even the 'father' of the community. The original group to which he belonged maintained a 'low Christology'.

- At the time when the Fourth Gospel was written, the inclusion of the Samaritans and other antiTemple groups led the group to confess a 'higher' Christology (Jesus viewed as the 'Man from Heaven'). Since traditional Israelite monotheists found this to be intolerable, conflict arose within the synagogue.

- When the letters were written, the community, having closed ranks against outsiders, seems to have migrated from Palestine to the region of Ephesus or some other city, like Syria, and confessed a higher Christology. The movement began to suffer, and its members were expelled from the synagogue. 
In his important multivolume commentary, The Gospel according to John, Raymond E. Brown (1966) offers a detailed introduction. The weakness of Brown's study is that it fails to offer a thorough interpretation of John 9 in connection with discipleship. The issue is alluded to in verses 24-41, conceived as 'the most cleverly written dialogues in the New Testament' (1966:377), but he does not comment on the first four verses (24-27), but rather concentrates on the ensuing verses. The expression 'disciples of Moses' is tackled as extrabiblical data as Brown claims the expression does not occur regularly (1966:374; also see Barrett 1978:300), and had been employed with regard to the Pharisees in a baraitah in Yoma $4 a$ and in the Midrash Rabbah 8.6 in Deuteronomy, where the Jews are warned that there is only one Law and that is the law Moses revealed. Unfortunately, Brown overlooks the need to compare this expression with the expression 'disciples of Jesus' to which it must have been opposed.

It is interesting that although Brown discerns that the blind man emerges as one of the foremost figures in the Gospels (1978:377), he fails to connect this emergence sufficiently with the struggles experienced by the Jesus movement Christian at the time of writing. Brown also fails to compare this figure with the character of the nameless disciples mentioned in all the Gospels.

In History and Theology in the Fourth Gospel (1979), Martyn differs from his predecessors in that he regards the tension and hostility between 'the Jews' and Jesus as the key to the purpose and historical life setting of John. Through a combination of exegetical and historical analysis, Martyn comes to the conclusion that many of the Gospel's dialogues and narratives should be understood as a parallel-level drama that speaks simultaneously about the lifetime of Jesus and about the Risen Lord who is redemptively active in the struggles and failures of the contemporary Johannine community. The main focus of Martyn's approach (1979:18) is to deal, as specifically as possible, with the circumstances surrounding the writing of the Fourth Gospel.

Martyn's reconstruction of the history of the Johannine community (1978:90-121; see also 2003:145-67) delineates three important periods, namely, the early, middle and late periods:

- The early period is characterised by the conception of Jesus as the promised Messiah.

- During the middle period, the confession that Jesus was the Messiah was perceived as a threat to established monotheism. From being a messianic group (that gathered momentum?) within the synagogue, the group (was expelled and so?) became a new community separated from its former social and theological setting.

- During the late period, the group evolved toward firm social and theological configurations that must be understood from three expressions:

- 'we are the disciples of Moses' (Jn 9.28)

- 'the Jews who believed in him' (Jn 8.31)

- 'there are other sheep' (Jn 10.16).
During the same period, the authorities laid down a new dictum: either a person was a loyal disciple of Moses and remained true to the ancient Jewish community, or one had become a disciple of Jesus and therefore ceased to be a disciple of Moses.

Schnackenburg, a Catholic professor at Wurzburg, produced a magisterial commentary on John in 1980. For many commentators, the description of the behaviour of the leaders, who oppress a man prepared to believe, who exercise pressure and terror upon their people (v. 22), who refuse to consider plausible arguments in favour of Jesus' divine origin (v. 30-34), forms the background to the pastoral discourse in chapter 10 , as will be demonstrated at a later stage.

Schnackenburg (1980b:238-239) contends that chapter 9 shows the evangelist's skill in using a loose 'historical' framework to deal with his theological themes and simultaneously to conduct a controversy with contemporary Judaism. The transparency with which the narrative reveals the underlying situation of the evangelist and his community is particularly great in John 9. The question of the Messiah is at the centre of the debate between Judaism and Christianity (v. 2). Official Pharisaic Judaism not only argues vigorously against Jesus' Messiahship and divine origin, but also fights the followers of Jesus Christ with external measures. Defectors are excluded from the Jewish religious community, and so become subject to social sanctions too (v. 34).

Schnackenburg rightly contends that John 9 is 'a masterpiece of narrative which combines theological and historical strands with dramatic skill' (1980b:239). The relevance of this point of view rests upon the fact that John, by recounting the story of the blind man, demonstrates his ability both to communicate the Gospel message and simultaneously to deal with the contemporary historical situation of (the evangelist and) his community, which is experiencing the central conflict between Judaism and Christianity over Jesus' messianic identity. In other words, the evangelist endeavours to use a 'loose historical framework' to deal with theology and to engage with the controversy in contemporary Judaism (Schnackenburg 1980b:238).

Schnackenburg's study is of great value since he is the only one amongst the commentators who offers a brief survey of the presence of the disciples (cf. excursus 1982:203-217). He contends that the greater frequency of the word $\mu \alpha \theta \eta \tau \eta \dot{s}$ (78 occurrences) is not a result of pure chance for, in the evangelist's thought and his own presentation of Jesus' advent, discipleship and the circle of the disciples are very important (1982:205). One may assume that the Johannine interest in Christology was kindled by Jesus' words and signs, his self-revelation and his confrontation with an unbelieving world. Schnackenburg aptly lists different instances where the disciples as a group make at least one appearance in the narrative (see 1982:205-206). According to him, the disciples are deliberately mentioned in the first part of the gospel to participate with Jesus in the activity in question and are actively involved in the event described (cf. Jn 2.2, 11, 12, 17, 
22, 6.5f.; 9.2; 11.54; 12.16, 20-22; 1982:206, n. 4). He concludes that John $4.27-38,9.2-5$ and $11.7-16$ are passages belonging to the evangelist and they were inserted at these particularly striking junctures because the circle of the disciples had a definite theological meaning in Jesus' work and activity on earth (1982:206). The disciples are included in three definite ways:

1. They represent the believers during Jesus' lifetime who became disciples through his word and his signs.

2. They represent the later community opposed by the unbelieving world.

3. They represent the later believers challenged and tempted in their faith.

Even though Schnackenburg views the man healed of blindness as being in sharp contrast to the Pharisees who play the part of 'disciples of Moses' (9.27f), he fails to demonstrate the important role played in this miraculous event by the disciples mentioned at the outset of chapter 9 . He contends, surprisingly, that the nameless disciples have a definite meaning in Jesus' work and activity. He contrasts these disciples who play no active part, but are nevertheless mentioned, in the narrative with the believers of inadequate faith who are represented in the story by the blind man's parents, by the worthy Nicodemus and Joseph of Arimathea elsewhere in the Gospel, and by the unbelieving world in general. Chapter 9, as a rhetorical piece of work, puts forward all three representations of Jesus' disciples. It could be viewed as a triple drama in connection with discipleship.

In his discussion of the discipleship witnessed in the Johannine community, Moody Smith (1999) argues that the conversation with the parents (9:18-23) and its reference to 'the ban' is probably 'the single most important bit of evidence for the circumstances of the Gospel's origin' (1999:194). The attribution of the Twelfth of the Eighteen Benedictions to the sage Samuel the Small, according to the proposal of Martyn and Davies regarding the mid-80s of the 1st century, demonstrates that in the post-resurrection time, the claims regarding the true identity of Jesus were sharply rejected and confessors were punished by 'the Jews'. Even though the dating of the version of the Twelfth Benediction remains a matter of some uncertainty, John 9.22 points to a real and not an imaginary situation (1999:196). According to Moody Smith (1999):

whatever the historical circumstances behind this scene, it is important to John that one must not only believe in Jesus but confess him as the Messiah and bear the cost of that confession. (p. 196)

Even under pressure from the Jews, the blind man is not prepared to deny the reality of his experience and is driven to confess that he believes Jesus is the Messiah. He is unique in that, after the miracle was performed, and despite his ignorance, he carries on a discussion with Jesus' opponents and refuses to deny the truth that he has discovered (see also Morris 1971:477-92). His belief is based on a 'firsthand experience that speaks louder than any theological assertions based on tradition received at secondhand' (1999:201).
The historical, theological significance of this episode was brought to the centre of attention by Martyn (1979). The now sighted man boldly confesses not to doctrine about Jesus, but to what Jesus has done for him, and is contrasted with his parents who frame a cautious answer for the Jews. The evangelist does not commend their behaviour (or attitude) for he wants believers to become confessors even at the cost of exclusion (12.42: cf. 16.2; 20.19).

Moody Smith points out that the Johannine Community, as a community of Jesus' disciples and their heirs, was based upon a brave and incautious confession, and for whom the blind man is a paradigm. Moody Smith unfortunately does not go on to demonstrate how Christological faith played a major role in the conflict that opposed Judaism and Christianity, and how the confession of Jesus as the Messiah must be related to the devotion to Jesus as plenary manifestation of God.

Andreas J. Köstenberger (2004) asserts that the progression in the man's estimate of Jesus (cf. Keener 2003:775) renders the blind man a 'paradigm of growing discipleship': from the 'man called Jesus' (v. 11) to 'a prophet' (v. 17), to one who might be followed by disciples (v. 27), to 'from God' (v. 33), to the 'Lord' to be worshipped (v. 38) (cf. Carson 1996:368). The expulsion from the synagogue, frequently considered as anachronistic (Martyn 1977, 1979; Brown 1979), revolves around the liturgical Eighteen Benedictions recited by all pious Jews three times a day (Schurer, as quoted by Köstenberger 2004:288). According to him, the agreement mentioned in John 9.22 need not reflect an official decision, and more likely points to an informal one. Therefore, the reference is most likely to be 'an incidental measure adopted ... with a view to a specific concrete situation'. ${ }^{1}$ Köstenberger agrees with other scholars that the same group that machinated the arrest and execution of Jesus sought, thereafter, to intimidate his followers further by threatening them with expulsion from the synagogue. However, the problem with that assertion is that it does not recognise the Jews contemporary to the authorship of the Gospel as the spiritual paradigm of the 'Jews' of Jesus' lifetime.

Köstenberger portrays the blind man as the model believer, through whom the readers are instructed that a person of committed faith ought to bear personal witness (see Carson 1991:373). Köstenberger has an interesting understanding of the disciple expressed in his concept of the 'paradigm of growing discipleship'. The concept is linked to the 'hermeneutics of progress' (or 'herméneutique étagéé/'herméneutique à degrés'; for details, cf. Theissen 2002:297-302; Zumstein 1991:249; id. 1993:60-62). Elementary belief, before it becomes authentic, has to grow, or mature, in order to reach the decisive recognition of the identity of Christ. It is this route which the blind man follows. Nevertheless, the commentary on chapter 9 does not include a detailed discussion of the conflict between Judaism and Christianity,

1.Cf. Köstenberger (2004:289); cf. Ridderbos (1997:343); Morris (1995:434, n. 36); contra Barrett (1978:361); Brown (1966:380); Schnackenburg (1990:2, 250); Bultmann (1971:335). 
the agency motif, or the relationship between seeing and hearing, all of which relate to discipleship. Köstenberger fails to demonstrate how the conflict goes beyond a simple witnessing about Jesus as the Messiah to seeing faith in Jesus as a threat to exclusive monotheism, and does not discuss the social, cultural and theological implications of expulsion from the synagogue.

This literature survey has sought to determine how scholars read chapter 9 by focusing on the worlds behind the texts. Brown and Martyn pinpoint how and when the original messianic group began to hold the confession of higher Christology and began to suffer persecution before it developed into a separate community outside its social and theological setting.

Schnackenburg, even though he sees John 9 as 'a masterpiece' that combines theological and historical strands and that the disciples had a definite theological meaning in Jesus' work and activity on earth, overlooks the blind man as a role model of the disciple. Moody Smith, basing his explanation of the conflict that arose from John 9.22, is convinced that the blind man's belief is grounded on first-hand experience. This experience speaks louder than any theological assertions based on tradition and received as second-hand information. However, he unfortunately fails to explain how Christology played a major role in the conflict and to relate discipleship to the devotion to Jesus acknowledged by the Early Jesus movement as the plenary manifestation of God. Köstenberger is one of the scholars who relates the expulsion from the synagogue to the Twelfth of the Eighteen Benedictions. He convincingly argues that the agreement, rather than reflecting an official decision, is an incidental measure adopted by the synagogue. He manages to portray the blind man as the model believer, but he focuses only on the confession and does not hint at the conflict from which the blind man emerges as a paradigm.

Since no research has been conducted on discipleship in the Fourth Gospel from the perspective of John 9, there is a need to address literary and theological problems. The small contribution of this article is to fill the gap left by the existing scholarship with regard to demonstrating how the blind man of John 9 emerges as a paradigm of the disciple living in an environment of conflict and ideological constructs. One has to take into account his audacious confrontation with Jewish authorities until he recognised Jesus as Son of Man and worshipped him.

\section{The expression 'disciples of Moses' Its source and its theological consistency}

The expression 'disciples of Moses', which does not occur anywhere else in the New Testament could be, in all probability, John's own creation. It is widely held that there is no commitment to an individual man in the Old Testament tradition along the lines of a master-disciple relationship; commitment is to God alone. The expression 'disciples of Moses' occurs in the scene where the blind man, for the second time, offers his defence before the Pharisees who, 'acting in a judicial capacity' (Petersen 1993:83), turn the interrogation into a legal debate (Keener 2003a:789). This leads them to judge Jesus as a sinner (v. 24b). The discussion that arises between the Jews and the blind man revolves around the issue of what the healer did and how the healing took place (v. 26), rather than who is the healer.

Their repeated question, Keener (2003a:790) notes, probably 'reflects traditional Jewish procedures for cross-examining witnesses' (e.g. Sus 48-62; m. 'Abot 1:9; cf. Mk 14:56). The Pharisees who are acting in their judicial capacity identify themselves as 'disciples of Moses' to whom God spoke. They do not reveal the slightest interest in becoming disciples of 'that fellow'. It seems, however, that here the issue of discipleship is closely related to the perception of the divine, with Moses being preferred over Jesus. Moses had become 'a legendary figure or the religious authority who gave the law to Israel and who mediates between God and Israel' (Harstine 2002:73). Judaism's grounding in Moses and the Law encapsulates the heart of Judaism's opposition to Christianity, which is grounded upon Jesus and his teaching (Beasley-Murray 1980:158; see also Carson 1991:374). Moses' authority emulates that of Jesus. The contrast (Keener 2003a:791 $)^{2}$ between these two figures is signified by a weight of emphasis in verse 28 ('you are his disciples' and 'we are disciples of Moses').

The expression 'the disciples of Moses', proudly used by the 'Jews' to describe themselves, is problematic as a subject for exegetical study. The famous classical commentators consulted on the Fourth Gospel did not give much attention to this. ${ }^{3}$ Moreover, the weakness of some of their comments is that they fail to highlight the strangeness of the expression, and to relate its meaning to the struggles between the synagogue and the church at the end of the 1st century. It is helpful to grasp the social and historical circumstances within which the expression is used. Barrett (1978:362)

2.For him the claim to be 'disciples of Moses' might be a means to echo genuine Pharisaic tradition (as this had been indicated earlier), since later rabbis came to speak of ultimately receiving tradition from Moses on Sinai (M. Abot 1.1; Ed 8.7; Abot R. Nat 25A; b. Qidd.30a; Meg.19b; Moed. Qat. 3b; Naz. 56b; Pesah. 110; Sabb. 108a; Eccl. Rab. 1.10; cf. perhaps 1 Cor 11.23). Moses was thought of as 'father of the prophets', and also their teacher and master (Abot R. Nat. 1A). For Moses as the greatest prophet and teacher, cf. also T.Mos.11.16. He was also viewed as the one who has saved his people (Josephus Ag.Ap.2.157; Acts 7.35). A later rabbi claimed that Moses is his teacher's teacher, the one who taught all the prophets (Pesiq. Rab. 31.3).

3.One could consult, for instance, Brown (1966) cf. supra; for Molla (1977:133). The evangelist employs irony when he recounts the rejection of Jesus as the Messiah and God's cf. supra; Schnackenburg (1980b:251), like many others, view the opposition between 'disciples of Moses' and 'disciples of Jesus' as another clear reference to the opposition between Jews and Christians in the evangelist's period. Morris (1995:438) states that the Pharisees, speaking from certainty, think that this gives them a sure basis, for God has spoken to Moses. The use of the perfect tense implies that God's word stands. Bruce (1983:219) notes that the tradition of oral law thought having transmitted in the rabbinical schools was held to stem from Moses, who they believed had received it on Sinai together with the written law'. Kysar (1986:154), being more precise, states that: 'With this declaration they have made their decision falsely between Moses and Jesus, and in this case against Jesus. The decision posed here is the tragic situation of the Christians and Jews in John's city, decision posed here is the tragic situation of the Christians and Jews in John's city, where embracing Christ was taken erroneously to be a rejection of Moses ...; Talber (1992:161) sees in the blind man's rhetorical question the implied declaration of his discipleship which had progressed from regarding Jesus as a man to speaking of him as a prophet. Witherington 11 (1995.184) thinks that the fact that the Pharisees do not know Jesus' origin and destiny must have led to the misunderstanding of Jesus and his work. By using the question 'Do you want to hear it again? Do you also want to become his disciples?' (v. 27b), the evangelist reverts to his habitual irony (see Hobbs 1968:162; Lindars 1972:348). 
argues that the formulation 'disciples of Moses' was not a regular term for rabbinic scholars. It is 'a typical phrase of Pharisaic scribes' (Schnackenburg 1980b:251), and found in later rabbinic sources as the self-designation of the Pharisees (baraitah in Yoma 4a) to distinguish Pharisaic from Sadducean teachers (Lincoln 2005:285). It also appears in rabbinic sources, for instance in $P$. Abot 5:19, 'How do the disciples of Abraham our father (the Jews) differ from the disciples (Christians) of "Balaam the wicked"' (cf. Barrett 1978:363). Jesus is viewed as Balaam (Str-B 2:535; cf. Beasley-Murray 1989:158). Through the formulation, John underscores the opposition, already revealed in the Sabbath healing, between Jesus and the Law, and why Jesus was considered to be a law-breaker. Another later principle of thought to which this term refers may be found in the Midrash Rabbah 8.6, grounded on Deuteronomy 30.11-14, ${ }^{4}$ where the Jews are warned that there is only one Law, namely the Law revealed by Moses.

The positive picture of the so-called 'disciples of Moses' that Van der Watt draws (2005:105-106) is twofold: (1) from a religious point of view, the identity of the opponents seems to be solid since they are aware of having received manna from God (6.31) and the Law from Moses (1.17; 5.45; 9.28-9.29). In addition, they trace their ancestry back to Abraham (8.33, $8.37,8.39-8.40)$ and even to God (8.41); (2) their religious activities point to a zealous devotion to God in the ways they knew and believed to be the best: they are pictured as active in Jerusalem and around the temple (2.14-2.16) where God is supposed to be worshipped (2.13; 4.20; 5.1; 10.22; 11.55). The scriptures were conceived as a cornerstone of their religious endeavours (5.39) and their devotion shows their wish to honour and serve God $(9.24 ; 16.2)$. That is why they were strict about their purity laws $(2.6 ; 11.55 ; 18.28 ; 19.42)$ and kept their religious feasts $(2.13 ; 5.1 ; 7.2,10 ; 11.55 ; 12.1$, 20; cf. Ashton 1994:39-40). One should understand why they persecuted the blind man who clung to Jesus. In conjunction with this, the leaders thought it only right to fight any revealer who claimed to come from heaven, since 'there is not going to be another Moses who will come down from heaven with a different law' (Brown 1966:374). The claim to be 'disciples of Moses' (9.28) is nothing less than a Johannine literary invention to refute ironically Jewish pretensions developed around the figure of Moses, who is one of the five witnesses to Jesus listed in Chapter 5 (cf. vv. 30-47)..$^{5}$ This passage is set in a longer section (5.1-47) dealing with Jesus who, after having healed a paralysed man on the Sabbath, is persecuted by 'the Jews' for violating the Sabbath and for blasphemy (5.18). The dominant theme of the whole chapter, notes Miller (2006:144), is testimony [ $\mu \alpha \rho \tau v ́ p i \alpha]$, since Jesus' words and actions are validated by the testimony of God himself (5.32). The figure of Moses links Chapter 9 to Chapters 1 and 5. According to Harstine (2002:59), the theme

4.'Moses said to them [the Israelites], "Lest you should say, "Another Moses is to arise and to bring us another Law from heaven," I make known to you at once that it is not in heaven; there is none of it left in heaven.' It was commonly admitted, in Jewish and perhaps also in Christian understanding, that only a God-worshipper $[\theta \varepsilon \sigma \sigma \varepsilon \beta \eta \dot{n} s]$ and the one who does God's will, can be sensitive to God or be able to communicate with God.

5.For instance: (1) the Father himself (vv. 32, 37); (2) the Baptist (v. 33), (3) the works that the Father has given him to complete (v. 36); (4) the scriptures (v. 39) and (5) Moses (v. 46) of glory revealed unifies all. When Jesus says (5.41), ' $\delta$ ó $\xi \alpha v$ $\alpha$ 'v $\theta \rho \omega ́ \pi \omega v$ oủ $\lambda \alpha \mu \beta \alpha ́ v \omega$ ' [I do not receive glory from humans], the

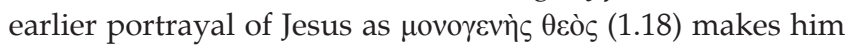
greater than these. Referring to the witness of the Father and the works he gives the Son to complete (5.36), the evangelist makes implicit reference to Jesus' glory, which puts into perspective the Baptist's testimony (5.33-5.34) which, like the testimony of other messengers who have pointed the way to Jesus, is derivative and their light merely reflective (cf. 5.35; Miller 2006:137-144).

If the evangelist shows suspicion of the reverence due to Moses, it is because the rejection of Jesus implies, at the same time, the rejection of God's glory, for Jesus coming in the Father's name means that he has come as the Father's representative (Keener 2003a:660). His testimony is greater than the testimony of those listed earlier. In accordance with the widespread principle of agency, Neyrey (2007:115; see also Hurst \& Wright 1987:239-250) argues that refusal to receive the king's agent is an insult to the king himself, for 'an agent is like the one who sent him' and 'the agent of the ruler is like the ruler himself' (Borgen 1968:138-44). It is questionable whether belief in Moses is possible if, at the same time, Jesus as the One sent and the Sender are rejected. The chiastic structure in verses 38 to 47 (see Keener 2003:658) demonstrates that the failure to have God's word abiding in them (v. 38) originates from the fact that they have never heard the Father's voice or seen his form (v. 37bc). Whilst the Old Testament attests that Moses saw God and spoke with him face to face (Ex 33.11; Nm 12.8) and heard his voice (Nm 7.89), in the evangelist's perspective, to Moses, in the light of Exodus 33.11, 18-28, was 'granted privileged insight into the nature of the divine glory' (Miller 2006:146). He was a witness to the signs and wonders that pointed to God's power. Jesus' greatness is underlined since, more than any other, he is God's word (Jn 1.1-18) and the Father's image (14.7-9; cf. 2 Cor 4.4; Col 1.15; Heb 1.3). According to Lincoln (2005:285), it is arguable that whereas the Pharisees make their clear allegiance to Moses to whom God spoke, the evangelist's rivalry is to assert not only that God has spoken to Jesus $(8.26,28)$ but also that Jesus embodies God's word as Logos (cf. 1.1, 2,14) and speaks God's words (cf. 3.34; 7.16; 12.49-50).

The Jews' lack of belief in both Moses and Jesus is explained by the Fourth Evangelist's use of the verb $\pi \imath \sigma \tau \varepsilon v \varepsilon เ v$, preceded by the particle eij in 5.46-5.47. The grammatical construct of this verse sets the protasis of unreal condition on one side [ $\varepsilon i$

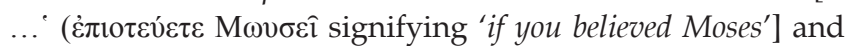

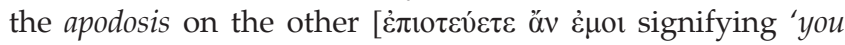
would believe in me']. The Jews who oppose both Moses and Jesus are nevertheless invited to bear in mind that Moses' witness should have prepared the Jews for Jesus' coming. The ironic overtone in this passage is that the Jews believed that Moses would be their defender (Talbert 1992:129-130), whilst in Jesus' understanding Moses no longer represented them (Barrett 1978:225; Morris 1995:334). The defendant will paradoxically become the accuser and Jesus, who is accused, finds in Moses and the writings his own witness to judge them. The foundational irony here, and throughout the 
Fourth Gospel, is that 'the Jews rejected the Messiah they eagerly expected' (Culpepper 1983:169).

When the Pharisees oppose Jesus against Moses, in John 9, the alleged 'disciples of Moses', ${ }^{6}$ the guardians of the Torah, are unable to explain the divine revealer about whom Moses wrote. Harstine (2002:71) argues that the Pharisees' passion for Moses' teaching and their obstinate refusal to look at the evidence force them to dismiss summarily the signs and teachings of Jesus without granting them proper consideration. The Fourth Evangelist is familiar with the ideology construed around the figure of Moses and disputes it by granting him the status of witness, as it is done for John the Baptist in Chapters 1, 3 and 5. The Fourth Evangelist contests the status granted to Moses, in attributing to him that of a witness or 'a burning and shining lamp' able to rejoice for a while (see Jn 5.35). However, what is that status in the Jewish world?

\section{Moses' status in Jewish religious imagery}

In the Pentateuch, Moses plays the role of king, prophet and priest and is portrayed, so to speak, as mediating God's affairs with Israel (Martin-Archard et al. 1978:17-29). Romer (2002:34,37) points out that Moses, as a character, had become an emblematic figure to the extent that during the exilic period the scribes, nowadays known as 'Deuteronomists', composed a chronicle of Israel's origins in which Moses plays a central role, not only as prophet and legislator, but as the mediator par excellence between Yahweh and his people. During the period of crisis, Moses, who inaugurated the long series of the prophets mandated by Yahweh, would remain the reference for the reconstruction of Israel's ideology.

The data given in Jewish literature regarding Moses as a type either of the Messiah or of some other eschatological figure must now be addressed. Jewish hopes for the Prophet may be found in three passages, namely (1) Deuteronomy 18.15, 18; (2) Psalm 74.9; and (3) 1 Maccabees 4.46, where reference is made to the expectation of the prophet. Moreover, referring to the scrolls of the Qumran community, two references determine the hope for a prophet like Moses, who is a definite eschatological figure distinct from the Messiah:

They [the members of the community] shall be judged by the first regulations in which in the beginning the men of the community were instructed until the coming of a prophet and the Messiahs of Aaron and Israel. (1 QS 9.10f)

This theory of two Messiahs clearly marked the priestly character of the religious party familiar with the Qumran texts in which the descendant of David is presented as being subject to the eschatological Priest. It is not surprising that the Essenes, strongly marked by their priestly adherence and their hierarchical structure, radically contested the cult of the

6.Moses was their teacher. The addition of oral law transmitted in the rabbinic schools was held to stem from Moses, who, they believed, had reed it on Sinai, together with the written law. There was a belief according to which 'Moses received the with the written law. There was a belief according to which "Moses received the law, i.e. the orallaw, from sinai and delivered it to Joshua, and Joshua to the elders, and the elders to the prophets delivered it to the men of the great synagogue' - and so it was transmitted to one generation of teachers after another.
Temple and the priesthood which came to be reorganised under Hasmonean leadership.

If these passages are combined, Jewish hopes should be summarised in three eschatological figures: (1) the Prophet like Moses alluded to in Deuteronomy 18.15; (2) the Messiah of Aaron (or Priestly Messiah); and (3) the Messiah of Israel (Kingly or Davidic Messiah); it is stated in the Qumran community that the prophet like Moses is a definite eschatological figure distinct from the Messiah. The token of the Messiah invites not only a projection into the future of the unfulfilled present claim, but also a memory taken from the past. The expected eschatological prophet refers to the survival of the figure of Moses, who remains the paradigm of the figure that has to precede the coming of the two anointed figures of Messiah. According to the paradigm idealised by primitive Israel, these are the leaders of two sectors of the community.

In the Qumran literature, for instance, the men of that community were to be instructed until the 'coming of a prophet and the Messiahs of Aaron and Israel'. Various eschatological figures are mentioned: a Jacob's star or the Messiah of Israel; a Redeemer like Moses, expected by the Samaritans - a Moses come back to life, called Taheb (Martyn 1979:108); and the Priestly Messiah or the Messiah of Aaron. Moses was considered as 'a type either of the Messiah or of some other eschatological figure' (Martyn 1979:106). The Samaritan Redeemer called Taheb was expected to repeat the great deeds of Moses, that is, he would perform Mosaic signs.

How did Moses become such an emblematic figure in Jewish imagery? To address this question one needs to turn back to 1 Maccabees 14.41, which alludes to Simon Maccabaeus who became national king and high priest at the same time - a conditional arrangement 'until a trustworthy prophet should arise'. Jewish hope was constructed on the expectation of the Prophet who had to play the role of king. Here one should refer to the people's reaction after the miracle of the multiplication of loaves in John 6.14-15, where the willingness to appoint Jesus as Prophet proves that the Jews expected the fulfilment of the promise of a future 'David' who would reign as king and deal wisely and righteously with God's people. That is to say that the coming Messiah or 'an anointed one' was thought of as a future anointed agent of Yahweh to be sent on behalf of his people (Fitzmyer 2000:79-80). Moses was perceived as 'mediator' par excellence amongst those who ministered in Israel, the only one worthy of such a title under the influence of Hellenism. However, as Meeks (1976:53) points out, 'there is no hint of any political office or leader in the Jewish community that could be identified with the idealized portrait of Moses', therefore the idea of Moses as 'mediator' could have emanated from the Hellenistic world where mediation has to do with divinisation.

The Greeks imagined their gods in human form, and believed that they manifested their presence in human conduct. These divine men, in the Hellenistic world, were seen as ligaments connecting the divine and human worlds (Van den Heever 
\& Scheffler 2001:30). They were 'mediators' who mediated between the world of the divine and the world of humans. In Philo's writings, not only Moses, but also Noah and Abraham are depicted at times as having intermediary status between the human and the divine. Moses remains the primary example to whom God said 'Stand here with me' (Dt 5.5).? Without thorough study of what Philo wrote about Moses, one might note that:

while Philo can use Moses, like Aaron, as a mere cipher for the philosopher's ultimate goal of perfection, he remains fascinated by the scriptural and traditional account of the Sinai ascent and of Moses having received the title theos, so that the legendary figure of Moses himself keeps breaking through the allegories.

(Meeks 1976:47)

The conception of Moses as a divine man was not far from the pagan Hellenistic conception of heroes. The cult of heroes stems from the fact that the Greeks imagined human beings as having divine abilities. Heroes were men of an earlier age who performed exceptional deeds in their lifetime, and it was believed that they still possessed some power after their death (Klauck 2000:262). A human being could be declared a 'hero' after death and could ascend to become a kind of demigod, in individual cases to the status of a 'daimôn', and ultimately to the status of a god. It seems that the 'Jews' living in the Diaspora came to be influenced by this perception of things and imagined Moses, after his death, as a demi-god.

The Pharisees' attachment to Moses, in the light of John 9.28f, is based on the belief that he is the Mediator between God and Israel, the only one to mediate God's affairs since the saving knowledge of God was attained and life might be found through him (Barrett 1978:270). The greatness of Moses should not be challenged by the greatness of any other, not even by Jesus.

The Jews maintained an attitude of obstinacy because of the

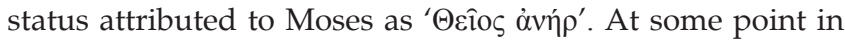
history, Moses became a divine figure. As already emphasised, Moses was regarded as both a king and a prophet (Kealy 1997:733). It was believed that he was enthroned in heaven, where he received the Torah (Ex 19.3-20.21; 34.2-9) and, with or within it, all truth (Meeks 1967:286). In the apologetic view, Moses was considered as God's emissary, agent or vice-regent on earth. From such a standpoint, Moses was exalted to the centre of religious concerns, the intermediary, in some sense, between them and God in Jewish traditions (Meeks 1976:286). The ascent of Moses to the mountain was an ascent to heaven to receive the Torah. In Jewish tradition, Enoch was believed to be exalted and worthy of the authority on heavenly mysteries, since he had been taken up to heaven before the flood (Gn 5.24). Therefore, he was pre-eminently qualified to disclose the mysteries of the heavenly world (Collins 1999:141).

The opposition shaped between Moses and Jesus stems from the exaltation of Moses as a transcendent figure. In the light of John 3, the Fourth Evangelist disputes that exaltation in

7.Som. $2.226-228$ quoted by Meeks (1976:46). a polemical stance. The statement in John 3.13, 'No one has ascended into heaven except the one who descended from heaven, the Son of Man', is a polemic addressed against the ascent of figures, amongst whom may be cited Moses, who was thought to have ascended to heaven to bring back revelation (McGrath 2001:160). Jesus, as the Son of Man, is polemically presented in contrast to some 'heroic mediators' (Keener 2003a:563, referring to Segal) or 'visionary mystics'. Unlike those figures, Jesus descended from above as the exclusive revealer of heavenly things. The central polemic in the Fourth Gospel, in Keener's opinion (2003a:563), probably exalts Jesus above Moses for he is 'from heaven' (3.13, 3.31; $6.38,6.41-6.42,6.50-6.51,6.58)$, or from God's realm (1.32; 3.27 ; 6.31-6.33; 12.28; 17.1). Moses was regarded as both a king and a prophet. In death, it was believed, he was enthroned in heaven (Holladay 1977:67), where he received the Torah and, with or within it, all truth (Meeks 1986:286). The meaning of the stranger expression, 'disciples of Moses', paves the way of learning about the concept of 'disciples of Jesus'.

\section{Meaning and implication of being a 'disciple of Jesus'}

In order to learn about the meaning and implication of the act of being a 'disciple of Jesus', one needs to refer to the ideology that exacerbated the conflict between the two groups, the Pharisees and the followers of Jesus, and to understand how the healed blind man, out of an environment of conflict, should be taken as the role model of the disciple. I will start with the ideology raised by the Jews' claim to 'know' or 'not to know'.

\section{The ideology construed around the claim 'to know' and 'not to know'}

The discussion about the knowledge of the Jews leads one to see how, in John 9, there is a strong opposition between 'to know' and 'not to know'. Behind this claim of the Jews lays an ideology rendering the conflict between Jews and Christians an 'epistemological conflict'. The 'Jews' are unshakably convinced by their insight that Moses is the one to come from God whilst the man born blind, representing the church, is convinced by the experience of the divine through his healing.

In order to learn about the ideology around the claim 'to know' or 'not to know', the particular use of the verb oit $\delta \alpha$ in John 9 is to be taken into account. The verb oif $\delta \alpha$ is abundantly used in these phrases, occurring seven times in as many verses (Jn 9.20.2, 9.21 [twice], 9.24.2, 9.29, 9.30.1, 9.31). The pronounced concentration upon oí $\delta \mu \mu \varepsilon v$ (affirmative form) and oủк oí $\alpha \mu \varepsilon v$ (negative form) alternate in these phrases to show to what extent the two groups (Jews and Christians) are opposed with regard to some kind of knowledge. The choice of the verb oit $\delta \alpha$ its used in a flexible manner, and the introduction of the figure of Moses cannot be gratuitous. It seems that John 9 provides some of the clearest and most straightforward instances of the objections raised by both 
Christians and Jews. The healing of the blind man as well as the debate that unfolds have theological and epistemological implications. The claim 'to know' or 'not to know' hides a kind of ideology.

In Chapter 9, the group of Pharisees contests Jesus' legitimacy. Whilst the light is found operating in the healing of the man born blind, the Pharisees, who refuse to recognise such a fulfilment, base their argument on what they 'know' and 'do not know', an argument counter-balanced by what the better experienced healed man 'knows' as well. The verb oi $\delta \alpha$ is abundantly used in John $9 .{ }^{8}$ By applying it in an elastic manner to both the healed man and the Jewish authorities, the writer seeks to bring out the religious conflict between the opposing groups, Jews fighting against Christian Jews. The Jewish authorities, blinded to higher levels of quality, try to gather more data or more information without new insight (Ravindra 2004:120). They claim to know that the healer is not from God but a sinner (v. 24), and to know that God has spoken to Moses, but they do not know where Jesus is from (v. 29). The healed blind man is not prepared to go into the theoretical question of whether Jesus is a sinner or not. The experience of the gift of sight is sui generis in the light of

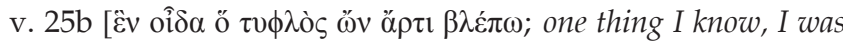
blind but now I see]. Hitting the nail on the head, the formerly blind man, opposed to the Pharisees' principle, reacts: 'We know (oí $\delta \alpha \mu \varepsilon v$ ) that God does not listen to sinners, but he does listen to one who worships him and obeys his will' (v. 31).

In the light of the phrase $\dot{\eta} \mu \varepsilon 1 \varsigma$ o' $\delta \alpha \mu \varepsilon v$ of v. 24 (see also v. 29), the emphatic 'we' of 'the Jews' is a reference to the Jewish authority they represent. This raises the existence of a theoretical principle on which their ideology is grounded.' The emphatic 'we' of the Pharisees' confession is contrasted with that of the blind man and the disbelief of the Pharisees is counter-balanced by the belief of the formerly blind man whose belief grows stronger (Lindars 1972:347). When the authorities say 'we know', they reject the marvellous restoration of sight because they cannot integrate it into their system of convictions (Zumstein 2003:173). The first oi $\delta \alpha$ used for them is grounded on 'their fine points of theology' or 'theoretical and dogmatic assumptions' (Morris 1995:436-437), whilst its use for the blind man is grounded in 'his experience' (cf. Hobbs 1968:164). The concept of 'to know' is used as an expression carrying the weight of official

8. Previously it was used for the neighbours and the parents' man only four times: firstly, for the blind man when his neighbours and acquaintances asked him where the man who opened his eyes is, he answered ovik oí $\delta \alpha$ (v. 12). Secondly, when his parents were asked to testify on how their son had been healed, they answered: parents were asked to testify on how their son had been healed, they answered:
'we know (oỉ $\alpha \mu \varepsilon v$ ) that this is our son ... how then he now sees we do not know

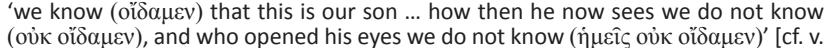
$20-21]$. In this present section (v. 24-34), the verb oí $\delta \alpha$ occurs seven times, three times with reference to the healed man and four times with reference to the Pharisees. I think that this abundant usage in a few verses led many scholars to claim that John 9 provides some of the clearest and most straightforward instances of the objections raised by both Christians and Jews.

9.Nicodemus emphatically speaks on the authorities' behalf by asserting: 'Rabbi, we know that you are a teacher who has come from God ', (In 3.2). Such an authority is matched by the man born blind with his own ' $k$ now' ' own experience. The Jows speak 'with responsibility and authority of Judaism, and own experience. The Jews speak 'with responsibility and authority of Judaism, and corren 1980 1980b:250-251). From the Jewish perspective there is no doubt that Jesus transgressed the Law by performing a healing on the Sabbath, which confirms that he is an $\dot{\alpha} \mu \alpha \rho \tau \omega \lambda \hat{o}$ s.
Pharisaic ideology and is, at the same time, used by the church to assert its experience.

Chapter 9 makes a clear breakthrough in portraying Jesus as being aware that he is doing the work of the One who sent him (v. 3) to be the Light of the world (v. 5). Jesus, as the Light of the World, is visibly evident in the unique healing of the man blind from birth. Such an extraordinary miracle legitimates Jesus' divine origin and reveals him as a miracleworker sent by God (see Jn 9.7c, 16.33; Schnelle 1992:124).

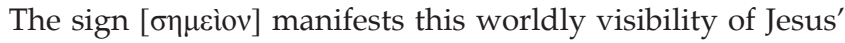
activity and the reality of his incarnation. The miracle is so marvellous as to demonstrate the healer as God's agent. ${ }^{10}$ The sign of healing a man born blind discloses the Messianic function of Jesus on the one hand, and on the other hand the deeper purpose of the sign is to establish the unity of being and action between God and his Son and to make God known.

The miracle in John 9 plays a Christological and theological role $^{11}$ insofar as it glorifies the Son, as it serves to disclose who Jesus is. That is to say that the signs and the works serve God's revelation. Yet when the Pharisees say to the healed man ' $\Delta$ ós $\delta$ ógav $\tau \hat{\omega} \theta \hat{\omega}$ ' [give glory to God], one should not be misled to think that it is indeed God they want to see glorified. Quite the reverse: the object of the Pharisees' tactic is to convince the man 'to repudiate Jesus and give glory to God'. ${ }^{12}$ The Pharisees seek to compel the man to withdraw his support from Jesus and to take up their sceptical view that Jesus is simply a human being. Whilst they claim that Moses is greater than Jesus, the open-minded formerly blind man has discovered the divine origin of Jesus. His understanding of Jesus develops into his understanding of Jesus' identity as the Son of Man and revitalises his willingness to be a paradigmatic figure in discipleship.

\section{The blind man of John 9 as an emblematic figure of discipleship}

The discussion that arises in Chapter 9 between the leaders and the formerly blind man not only shows us two distinct groups of disciples, but also highlights the religious and mutual exclusion between both groups. The dictum implied that either one is a loyal disciple of Moses, remaining true to the ancient Jewish community, or one has become a disciple

10.Marrow points out that 'a wonder like this is God's alone to perform and to perform solely through his own chosen agent' $(1995: 156)$. The miracle per se is to be (v. 33). Whilst the theoretical expertise of the leaders does not enable them to understand God's way of revelation, yet the narrator shows the formerly blind to understand God's way of revelation, yet the

11.For more details about the theological significance of the 'signs', I refer to Schnackenburg's Excursus (190a), pp. 521-525.

12.Witherington (1995:184; see also Kysar [1986:153]) disputes that all consideration of this must be taken as an injunction to the man to attribute his healing to God and not to Jesus. For him, 'Give God the praise' could mean the formal oath required before offering testimony (cf. Jos 7.19 and 1 Esdr 9.8). The oath 'Give glory to God' is an OT formula used to stress Yahweh's unique claim to worship in order to induce is an OT formula used to stress Yahweh's unique claim to worship in order to induce people to admit their guilt before God (see Jos 7.19; $1 \mathrm{Sm} \mathrm{6.5;} \mathrm{Jr} \mathrm{13.16).} \mathrm{According}$ to Talmudic literature (bSanhedrin 6.2), a condemned criminal like Achan (Jos 7.19) gives praise by making a confession of sin. For the Pharisees, Jesus, by healing on the Sabbath, was indeed a sinner and thus the blind man taking the part of a sinner is making him guilty. I am not convinced by Beasley-Murray's (1989:158) assertion that this is the command to the man to confess his sin related to his blindness and subsequent healing by Jesus. 
of Jesus, thereby ceasing to be a disciple of Moses (Martyn 2003:158). The figure of Moses, so emblematic in Judaism, represents the Torah. Whilst in the Old Testament one is obedient to God or God is to be found through the Torah, in the New Testament, however, God is to be found through Jesus. The obedience to God can no longer be conceived without following Jesus, the one through whom God makes himself known on earth.

Reading John 9 brings forth two different worldviews, that of the 'Jews' and that of the Christian church, each of which excludes the other. The 'Jews,' as the dominant local group, are depicted as concerned by their self-definition and the need to ensure the survival of Judaism. In their struggles to contain the growth of Christianity towards the end of the 1st century, they rejected the Christian confession and Pharisees were powerful authorities. By making the Johannine Christians 'synagogueless', the penalty implied social dislocation and alienation from their social and theological womb.

The conflict between 'Jews' and Christians is conceived as a 'conflict between darkness and light'. Towards the end of the 1st century, holding to Moses, representing the Torah should be taken as a way of darkness whereas following Jesus, in contrast, is a way of light. The formerly blind man triumphs over darkness, and contrasts, so to speak, with the Pharisees who misguidedly follow the way of darkness and reject God's self-revelation. In that sense, discipleship in John 9 is firstly characterised not just as simple enthusiasm and zeal, but rather a firm commitment, and strong and courageous determination to bear witness based upon an experience of the divine. Disciples are required to maintain their readiness for struggles, even death, for the sake of their faith. Secondly, it is conceived as redefining the believer's covenant relationship with God which takes place through Jesus' identity and work. For the Fourth Evangelist, since Jesus' coming, the notion of 'disciples of Moses' is no longer defensible as God is to be found through Jesus, depicted as the only one worthy of honour and loyalty. Jesus' legitimacy is beyond any traditional legitimacy. Jesus, as the sent One, is not only in close cooperation with the Father, but also shares the same privileges and authority with him since he is enabled to work the works of God. The healed man's progress to understanding Jesus' identity becomes a paradigm for walking in the light and moving away from the perceptible darkness of the Jewish world. Abandoning the world he is familiar with (the synagogue and his own parents), the man born blind steps over the threshold that leads to a new world mediated by the Johannine community where discipleship is so radicalised and conceived as an attachment in faith to Jesus as Son of Man, or the Son acting in close cooperation with the Father.

\section{Conclusion}

In order to understand how the blind man of John 9 emerges as a paradigm of the disciple the survey of the literature revealed the gap left by scholarship. They forget to explain how Christology played a major role in the conflict that constructs the narrative of John 9 and to relate discipleship to the devotion of Jesus as Son of man. The Pharisees, acting in their judicial capacity, identify themselves as 'disciples of Moses', a nonregular term for rabbinic scholars. The Pharisees' passion for Moses' teaching leads them to dismiss Jesus' signs and teachings.

Whilst the figure of Moses is ideologically constructed in Jewish religious imagery as prophet or king, God's emissary, agent or vice-regent on earth, the mediator par excellence between God and Israel and exalted to the centre of religious concerns, the Fourth Evangelist strives to polemically exalt Jesus above Moses since he is from above (3.13, 3.31; 6.38, $6.41-6.42,6.50-6.51,6.58)$, or from God's realm $(1.32 ; 3.27$; $6.31-6.33 ; 12.28 ; 17.1)$. The story of John 9 is the evangelist's endeavour to give Jesus primacy and authority that exceeds that granted to Moses.

The conflict around the figure of Moses and Jesus from which the blind man emerges as role model of the disciple between Jews and Christians, rendered by the claim 'to know' or 'not to $\mathrm{know}^{\prime}$ ' is nothing other than an 'epistemological conflict'. Both groups are opposed with regard to some kind of knowledge. The concept 'to know' is used in an elastic manner and whilst the expression carries the weight of official Pharisaic ideology it is, at the same time, used by the Church to assert its own experience of the divine as it operates in Jesus. The healing of the blind man and the debate that unfolds has theological, christological and epistemological implications. The Pharisees, blinded to higher levels of quality, trying to gather more data or more information without new insight, contest Jesus' legitimacy because they reject the marvellous restoration of sight because they cannot integrate it into their system of convictions. The miracle of the blind man manifests the worldly visibility of Jesus' activity and the reality of his incarnation. The miracle is marvellous and demonstrates the healer as God's agent; the open-minded formerly blind man has discovered the divine origin of the healer (theological aspect). The Christological role of the miracle is that it glorifies the Son as it serves to disclose who Jesus is. The formerly blind man experiences the light operating in his healing (epistemological aspect) and the understanding of Jesus develops into his understanding of Jesus' identity as the Son of man and revitalises his willingness to be a paradigmatic figure in discipleship.

The conflict between Jews and Christians is conceived by the Fourth Gospel as a 'conflict between darkness and light'. The open-minded formerly blind man, as the disciple, by audaciously keeping on following Jesus, triumphs over darkness, and contrasts, so to speak, with the Pharisees who misguidedly follow the way of darkness and reject God's revelation.

In that sense, discipleship is firstly characterised not just by simple enthusiasm and zeal, but rather a firm commitment, and strong and courageous determination to bear witness based upon an experience of the divine. Disciples are required to maintain their readiness for struggles, even death, for the 
sake of their faith. It is secondly conceived as redefining the believer's covenant relationship with God which takes place through Jesus' identity and work. The healed man's progress to understanding Jesus' identity is therefore a paradigm for walking in the light and moving away from the perceptible darkness of the Jewish world.

\section{Acknowlegdements Competing interests}

The author declares that he has no financial or personal relationship(s) which may have inappropriately influenced him in writing this article.

\section{References}

Barrett, C.K., 1978, The gospel according to St John, SPCK, London.

Beasley-Murray, G.R., 1989, John, Word Publishing, Dallas, TX.

Borgen, P., 1968, 'God's agent in the Fourth Gospel', in J. Neusner (ed.), Religions in Antiquity: Festschrift E. Goodenough, pp. 137-148, Brill, Leiden.

Brown, R.E., 1966, The gospel according to John, 2 vols., Geoffrey Chapman, London. Brown, R.E., 1978, The community of the Beloved Disciple, Geoffrey Chapman, London. Carson, D.A., 1991, The gospel according to John, Inter-Varsity Press, Leicester. Collins, J.J., 1999, Dead Sea Scrolls after fifty years, vol. 2, E.J. Brill, Leiden.

Culpepper, R.A., 1983, Anatomy of the Fourth Gospel: A study in literary design Fortress Press, Philadelphia, PA.

Harstine, S., 2002, Moses as character in the Fourth Gospel: A study of ancient reading techniques, JSNTS 229, Sheffield Academic Press, Sheffield.

Hobbs, H.H., 1968, An exposition of the Gospel of John, Baker Book House, Grand Rapids, MI.

Kealy, S.P., 1997, John's gospel and the history of biblical interpretation (Book 2), Edwin Mellen Press, Lewiston/Queenston/Lampeter.

Keener, C.S., 2003, The gospel of John: A commentary, vol. 1, Hendrikson Publishers, Peabody, MA.

Klauck, H.J., 2000, The religious context of early Christianity: A guide to Graeco-Roman religions, T\&T Clark, London.

Köstenberger, A.J., 2004, John, ECNT, Baker Academic, Grand Rapids, MI.

Lincoln, A.T., 2005, The Gospel According to Saint John, Continuum/Hendrickson Publishers, London.

Lindars, B., 1972, The Gospel of John, Oliphants, London.

Martin-Achard, R. et al., 1978, La figure de Moise : écriture et relectures, Publications de la Faculté de Théologie de Genève 1, Labor et Fides, Genève.
Martyn, J.L., 1968, History and theology in the Fourth Gospel, Harper \& Row Publishers, New York.

Martyn, J.L., 1978, The gospel of John in Christian history: Essays for interpreters, Paulist Press, New York.

Martyn, J.L., 1979, History \& theology in the Fourth Gospel, rev. and enl. edn. Parthenon Press, Nashville, TN.

Martyn, J.L., 2003, History and theology in the Fourth Gospel, 3rd edn., John Knox Press, Louisville, KY.

McGrath, A.E., 2001, Christian theology: An introduction, Blackwell Publishers, Oxford/Malden.

Neyrey, J.H., 2007, The gospel of John, Cambridge University Press, Cambridge.

Nickelsburg, G.W.E., 2003, Ancient Judaism and Christian origins: Diversity, continuity and transformation, Fortress Press, Philadelphia, PA.

Moody Smith, D., 1999, John, Abingdon NT Commentary, Abingdon Press, Nashville, TN.

Morris, L., 1971, The gospel according to John, Marshall, Morgan \& Scott, London.

Miller, P., 2006, 'They saw His glory and spoke of Him: The gospel of John and the OT', in S.E. Porter (ed.), Hearing the Old Testament in the New Testament, pp. 127-151, William B. Eerdmans Publishing Company, Grand Rapids, MI/Cambridge.

Meeks, W.A., 1967, The Prophet-King. Moses traditions and the Johannine Christ, Brill, Leiden.

Meeks, W.A., 1976, 'The Divine Agent and His Counterfeit', in E.S. Fiorenza (ed.) Aspects of Religious Propaganda in Judaism and Early Christianity, pp. 43-67, University of Notre Dame Press, Notre Dame.

Meeks, W.A. (ed.), The interpretation of John, T \& T Clark, Edinburg.

Römer, T., 2002, Moïse 'Lui que Yahvé a connu face à face, Gallimard, Paris.

Schnackenburg, R., 1980a, The gospel according to John, vol. I, Burns \& Oates, London.

Schnackenburg, R., 1980b, The gospel according to John, vol. II, Burns \& Oates, London.

Schnackenburg, R., 1982, The gospel according to Saint John, Burnes \& Oates, Crossroad/New York.

Schnelle, U., 1992, Antidocetic Christology in the gospel of John: An investigation of the place of the Fourth Gospel in the Johannine School, Fortress Press, Minneapolis, $\mathrm{MN}$

Talbert, C.H., 1992, Reading John: A literary and theological commentary on the Fourth Gospel and the Johannine Epistles, SPCK, London.

Theissen, G., 2002, La religion des premiers chrétiens. Une théorie du christianisme primitif, Traduit de l'allemand par J Hoffmann (Initiations au Christianisme ancien), Cerf/Labor et Fides, Paris/Geneve.

Van den Heever, G. \& Scheffler, E. (eds.), 2001, From Jesus to Christianity: Early Christian literature in context, Unisa Press, Pretoria.

Van der Watt, J.G., 2000 [2005], 'Salvation in the Gospel according to John', in J.G. van der Watt (ed.), Salvation in the New Testament: Perspectives on Soteriology, pp. 101-131, Leiden/Boston, Brill.

Zumstein, J., 1991, 'L'évangile johannique: une stratégie du croire', in J. Zumstein (ed.), Miettes Exégétiques, pp. 237-252, Labor et Fides, Geneve.

Zumstein, J., 1993, L'Apprentissage de la foi. A la découverte de l'évangile de Jean et de ses lecteurs, ed. du Moulin SA Aubonne, Poliez-le-Grand.

Zumstein, J., 2003, 'Crise du savoir et conflit des interprétations selon Jean 9: Un exemple dutravailde l'école johannique', in D.H. Warren, A.G. Brock \& D.W. Pao (eds.), Early Christian Voices: In Text, Traditions, and Symbols: Essays in Honour of Francois Bovon, pp. 167-178, Brill Academic Publishers, Boston, MA. 